\title{
Phylogenetic analysis of VP2 gene of canine parvovirus and comparison with Indian and world isolates
}

\author{
G. KAUR, M. CHANDRA, P. N. DWIVEDI
}

\begin{abstract}
Department of Veterinary Microbiology, College of Veterinary Science, Guru Angad Dev Veterinary and Animal Sciences University,
\end{abstract} Ludhiana-141001 Punjab, India

Received June 12, 2015; revised July 22, 2015; accepted February 18, 2016

\begin{abstract}
Summary. - Canine parvovirus (CPV) causes hemorrhagic enteritis, especially in young dogs, leading to high morbidity and mortality. It has four main antigenic types CPV-2, CPV-2a, CPV-2b and CPV-2c. Virus protein 2 (VP2) is the main capsid protein and mutations affecting VP2 gene are responsible for the evolution of various antigenic types of CPV. Full length VP2 gene from field isolates was amplified and cloned for sequence analysis. The sequences were submitted to the GenBank and were assigned Acc. Nos., viz. KP406928.1 for P12, KP406927.1 for P15, KP406930.1 for P32, KP406926.1 for Megavac-6 and KP406929.1 for NobivacDHPPi. Phylogenetic analysis indicated that the samples were forming a separate clad with vaccine strains. When the samples were compared with the world and Indian isolates, it was observed that samples formed a separate node indicating regional genetic variation in CPV.
\end{abstract}

Keywords: canine parvovirus; VP2 gene; cloning; sequence analysis; phylogenetic analysis

\section{Introduction}

Canine parvovirus (CPV) (the family Parvoviridae, the genus Parvovirus) is an important cause of severe enteritis and systemic disease in dogs throughout the world. It spreads rapidly in the domestic as well as wild population of canines. CPV-2 was first recognised in 1978 (Carmichael et al., 1994) and antigenic variants of CPV-2, viz. CPV-2a, CPV-2b, CPV-2c, have been circulating in dog populations worldwide since then (Decaro et al., 2006). The origin of $\mathrm{CPV}$ is poorly understood and is thought to have phylogenetically originated from the feline panleukopenia virus or a very closely related carnivore parvovirus of feral canids like foxes and mink (Mochizuki et al., 2008). CPV possesses a high genetic substitution rate, which is responsible for its antigenic evolution and rapid displacement of old by new antigenic variants (Shackelton et al., 2005). In India, CPV was first reported in 1982 (Ramadass and Khader, 1982) and

E-mail: gurpreet7502@rediffmail.com; phone: +91-161-2414033. Abbreviations: $\mathrm{CPV}=$ canine parvovirus; $\mathrm{LB}=$ Luria Bertani; $\mathrm{ORF}(\mathrm{s})=$ open reading frame $(\mathrm{s}) ; \mathrm{VP} 2=$ virus protein 2 since then a large number of outbreaks have been reported from different parts of India in dogs involving CPV variants, viz. 2a, 2b and 2c (Biswas et al., 2006; Chinchkar et al., 2006; Nandi et al., 2009a,b; Singh et al., 2014).

The genome of CPV is approximately $5.3 \mathrm{~kb}$ and has two open reading frames (ORFs); ORF1 and ORF2. ORF1 encodes two non-structural proteins, NS1 and NS2, and ORF2 encodes two capsid proteins, VP1 and VP2 (Ying et al., 2009). VP2 has an important role in determination of antigenicity of CPV (Phromnoi et al., 2010) and thus, mutations affecting VP2 are mainly responsible for the evolution of different antigenic variants of CPV (Mochizuki et al., 1993).

Therefore, sequencing and phylogenetic analysis of full length VP2 gene will provide information on the prevailing antigenic types of CPV in Ludhiana district of Punjab, India and its comparison with vaccines will provide information on the escape mutants in clinical cases of CPV.

\section{Materials and Methods}

Amplification of full length VP2 gene. For the amplification of full length VP2 gene of CPV, a total of 30 samples i.e. rectal swabs 
Table 1. Primers for the amplification of full length VP2 gene of CPV

\begin{tabular}{|c|c|c|c|c|c|c|}
\hline Primer & Sequence & Acc. No. & & $\begin{array}{c}\text { Position in } \\
\text { genome }\end{array}$ & $\begin{array}{c}\text { Annealing } \\
\text { temperature } \\
\left({ }^{\circ} \mathrm{C}\right)\end{array}$ & $\begin{array}{l}\text { Product size } \\
\text { (bp) }\end{array}$ \\
\hline VP2 GMCOM F & 5'-GGTCAACCTGCTGTCAGAAA-3' & \multirow[t]{2}{*}{ M19296.1 } & \multirow{2}{*}{$\begin{array}{l}\text { Whole genome of } \\
\text { CPV }\end{array}$} & $2816-2835$ & \multirow[t]{2}{*}{58} & \multirow[t]{2}{*}{1710} \\
\hline VP2 GMCOM R & 5'-AGGTGCTAGTTGAGATTTTTCAT-3' & & & $4525-4503$ & & \\
\hline
\end{tabular}

detected positive via PCR and nested PCR, were selected from a total of 100 samples collected from dogs exhibiting clinical signs of CPV, viz. gastroenteritis, hemorrhagic enteritis, pyrexia etc., from small animal veterinary clinics, Guru Angad Dev Veterinary and Animal Sciences University, Ludhiana, Punjab from June 2013 till January 2014. All rectal swabs were kept at $4^{\circ} \mathrm{C}$ till further use. In addition, two commercially available vaccines [Nobivac DHPPi (Intervet, Pvt. Ltd.) and Megavac-6 (Indian Immunologicals)] procured from local market in Ludhiana were used for the amplification of VP2 gene. DNA was extracted from the samples and the two vaccines using the phenol-chloroform extraction method (Sambrook and Russell, 2001).

Primer designing. The primer pairs for the amplification of full length VP2 gene were designed using Primer3 (Rozen and Skaletsky, 2007) (accession no. M19296.1) (Table 1).

Polymerase chain reaction (PCR). The PCR was set up by adding $1 \mu \mathrm{l}$ of the template DNA, $10 \mu \mathrm{l}$ of $5 \mathrm{X}$ longAmp reaction buffer (with $2 \mathrm{mmol} / \mathrm{l} \mathrm{MgSO}_{4}$ ), $1 \mu \mathrm{l}$ of forward and reverse primer (20 $\mathrm{pm} / \mu \mathrm{l}$ ) each, $1 \mu \mathrm{l}$ of dNTPs mix ( $10 \mathrm{mmol} / \mathrm{l}$ each), $0.5 \mu \mathrm{l}$ of $\mathrm{MgCl}_{2}$ (50mmol/l), 2.5 U LongAmp Hot start Taq DNA polymerase and the reaction was made up to $50 \mu \mathrm{l}$ using nuclease free water. The reaction proceeded in a thermocycler (Veriti ${ }^{\oplus}$, Life Technologies, USA) and under following conditions: 35 cycles of denaturation at $94^{\circ} \mathrm{C}$ for $60 \mathrm{sec}$, annealing at $58^{\circ} \mathrm{C}$ for $60 \mathrm{sec}$, elongation at $72^{\circ} \mathrm{C}$ for $150 \mathrm{sec}$ and a final elongation at $72^{\circ} \mathrm{C}$ for $10 \mathrm{~min}$. The PCR products were run using $1 \%$ agarose at 5 volts $/ \mathrm{cm}$ with Gene Ruler ladder $1 \mathrm{~Kb}$ (New England Biolabs, USA) and the gel was visualized and photographed using Gel documentation system (AlphaImager, USA).

Cloning of full length VP2 gene. The samples, in which PCR amplified VP2 gene, were first cleaned up using an UltraClean ${ }^{\circ}$ PCR Clean-Up kit (Mo Bio Labs., Inc. USA) following manufacturer's instructions and then cloned using pGEM-T vector cloning kit (Promega, USA) and Top 10 strain of Escherichia coli (procured from the School of Animal Biotechnology, GADVASU, Ludhiana) as a host system for the transformation of recombinant plasmid vector. Briefly, the cleaned up PCR products and pGEM-T vector were ligated by preparing a $10 \mu$ ligation mixture containing 3 $\mu \mathrm{l}$ of cleaned up PCR product, $5 \mu \mathrm{l}$ of $2 \mathrm{X}$ Ligation buffer, $1 \mu \mathrm{l}$ of pGEM-T vector $(50 \mathrm{ng} / \mu \mathrm{l})$ and $1 \mu \mathrm{l}$ of T4 DNA ligase (3 Weiss units/ $\mu \mathrm{l})$. The ligation reaction was set up in a water bath at $22^{\circ} \mathrm{C}$ for $30 \mathrm{~min}$ and then kept at $4^{\circ} \mathrm{C}$ overnight. Transformation in the competent cells (Top 10 strain of E. coli) was done using snap hot cold method (Sambrook and Russell, 2001). The clones were grown on Luria Bertani (LB) agar plates containing 20\% w/v, 0.8 M IPTG (400 $\mu \mathrm{l} / 100 \mathrm{ml}$ of media), $2 \% \mathrm{w} / \mathrm{v} \mathrm{X}-\mathrm{gal}(800 \mu \mathrm{l} / 100 \mathrm{ml}$ of media) and $100 \mathrm{mg} / \mathrm{ml}$ ampicillin $(100 \mu \mathrm{l} / 100 \mathrm{ml}$ of media) to obtain blue and white colonies.

Approximately three white colonies from LB agar plates were inoculated in $10 \mathrm{ml}$ of LB broth with $100 \mu \mathrm{g}$ ampicillin/ml and incubated in a shaker incubator (Thermo Scientific, USA) at $37^{\circ} \mathrm{C}$ overnight for plasmid extraction. The plasmid was extracted using an UltraClean 6 Minute Mini plasmid prep kit (Mo Bio Labs., Inc. USA). The recombinant plasmid was gel electrophoresed using $1.5 \%$ agarose at 5 volts $/ \mathrm{cm}$ along with Gene Ruler ladder $1 \mathrm{~kb}$ (New England Biolabs, USA) and the gel was visualized and photographed using Gel documentation system (AlphaImager, USA) for confirmation.

Sequence analysis of full length VP2 gene. Five recombinant plasmids, i.e. three from clinical samples (randomly selected) and two from vaccines, were sequenced at Invitrogen (India) and submitted to NCBI. These were analysed and compared with the available CPV sequences in GenBank using BLAST and Multiple sequence alignment software (Clustal Omega). Phylogenetic analysis of the sequences was also done using Mega6 (Tamura et al., 2013). These sequences were compared with the available Indian and world CPV VP2 sequences for phylogenetic analysis using Mega6 (Tamura et al., 2013).

\section{Results}

Full length VP2 gene of CPV was amplified from a total of 30 clinical samples and two vaccines using the designed primers that amplified a $1710 \mathrm{bp}$ product (Fig. 1). The cleaned up PCR product was confirmed by agarose gel electrophoresis. After ligation and transformation of the cleaned PCR product, plasmid of approximately 4725bp (3015+1710bp) was obtained.

Out of these 30 recombinant plasmids, five recombinant plasmids, i.e. three of samples and two of vaccines, were sequenced at Invitrogen (India). When analysed using BLAST and multiple sequence alignment (Clustal Omega), multiple sequence alignment of the nucleotide sequences of the samples (P12, P15, P32) and the vaccines (Nobivac DHPPi and Megavac-6) revealed that all the samples belonged to the CPV-2a antigenic type but the vaccine was not found to be of the same type. Phylogenetic analysis of nucleotide 


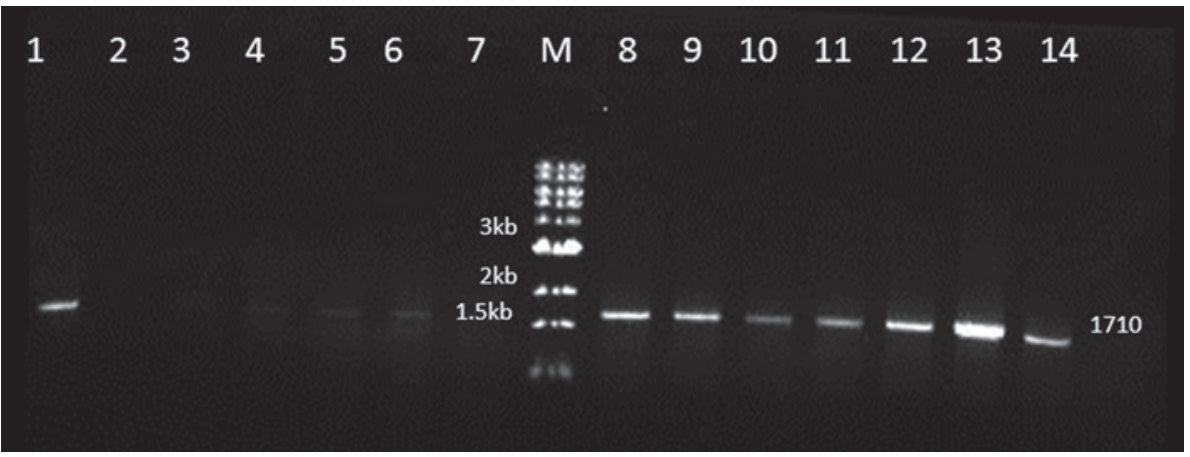

Fig. 1

PCR for the amplification of VP2 gene of CPY

Gene ruler $1 \mathrm{~Kb}(\mathrm{M})$. Positive control (1). Negative control (2). Samples $(3,4,5,6,7,8,9,10,11,12,13,14)$.

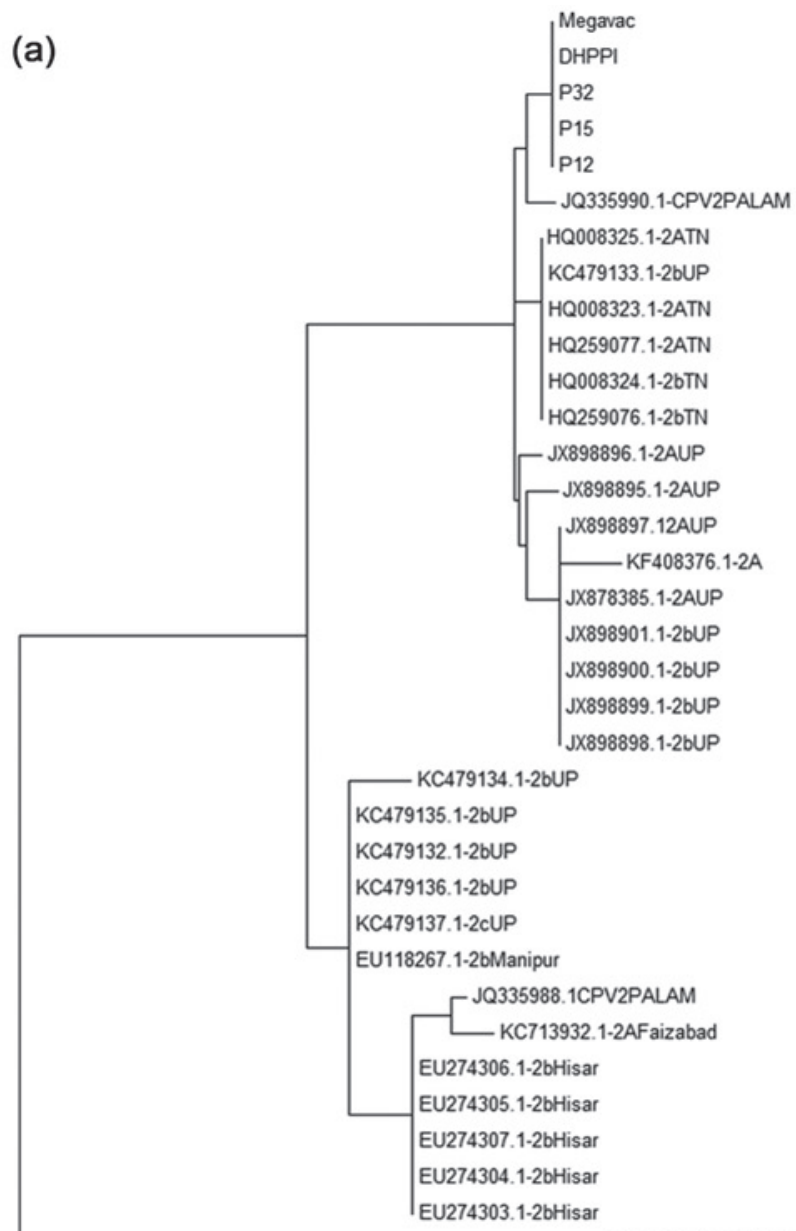

(b)

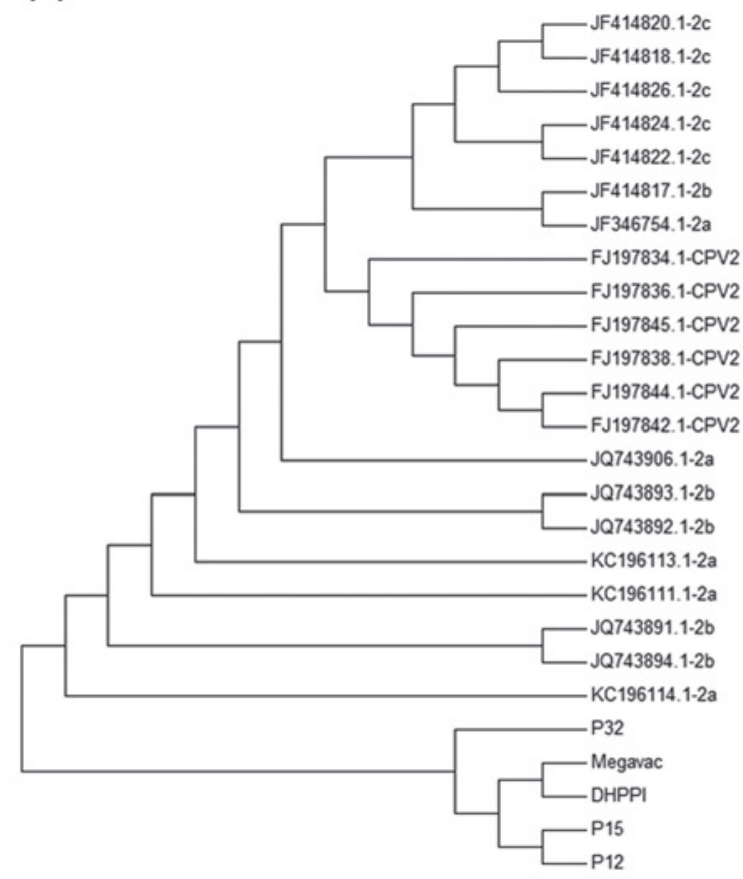

335991.1.CPV2PALAMVP2

JQ335980.1-CPV2PALAM

JQ335984.1-2APALAM

Fig. 2

Phylogenetic analysis of cloned VP2 gene of CPV samples and vaccines with Indian (a) and world (b) isolates using Mega6 (a) Scale of tree (5). Number of sequences compared $(32+5)$. (b) Scale of tree (2). Number of sequences compared $(21+5)$. 
sequences from samples and vaccine strains revealed that all sequences in the present study formed a separate node from rest of the Indian (Fig. 2a) and worldwide isolates (Fig. 2b). This indicates a regional variation in the CPV isolates, since the clinical samples in this study were from dogs in Ludhiana district of Punjab.

Three sequences from the samples and the two sequences from vaccines were submitted to the GenBank and were assigned GenBank Acc. Nos. KP406928.1 for sample P12, KP406927.1 for sample P15, KP406930.1 for sample P32, KP406926.1 for Megavac-6 and KP406929.1 for NobivacDHPPi.

Based on the BLAST comparison of the sample and vaccines sequences, we found that all had $100 \%$ homology with the Canine Parvovirus.

\section{Discussion}

Canine parvovirus has emerged as one of the most important diseases of pups in recent years. The virus is prone to genetic evolution and has undergone several mutations, which has led to several antigenic variants of CPV-2 that have replaced the original CPV-2 (MohanRaj et al., 2010). There are currently three main antigenic variants, i.e. $2 \mathrm{a}, 2 \mathrm{~b}$ and $2 c$, circulating in the dog population worldwide (Decaro et al., 2006). Majer-Dziedzic et al. (2011) reported that the mutations in the original CPV-2 strains and the appearance of the variants $(2 a, 2 b$ and $2 c)$ is due to the specific amino acid changes mainly in the capsid protein VP2. The VP2 is the immunodominant protein of CPV and is important in the determination of antigenic types based on the epitopes located on the VP2 protein. Thus, the mutations affecting VP2 are mainly responsible for the evolution of different antigenic variants of CPV (MohanRaj et al., 2010). Moreover, as this gene is under positive selection in CPV, it results in a significantly elevated rate of molecular evolution (Hoelzer et al., 2008). Thus, full length VP2 gene was amplified, sequenced and phylogenetically analysed to study the changes, if any, in the VP2 gene from the isolates circulating in the region under study so that prevailing antigenic types of CPV in dogs may be known.

The sequence analysis of the isolates in our study revealed that they belonged to the CPV-2a type. In India, Chinchkar et al. (2006) studied the epidemiology of CPV infection in dogs and found that CPV 2 a was predominant over CPV $2 b$ variant in Central and Southern India, whereas Parthiban et al. (2012) reported CPV 2b as the major type in Tamil $\mathrm{Nadu}$, India. Nowadays it has been observed that new types of CPV have been reported, viz. New CPV-2a, New CPV-2b etc., which are antigenically different from the earlier reported CPV types, and hence continuous surveillance is required. Thus, different studies in India have revealed that different variants of CPV are prevailing in different regions of India.

Similarly, the trend of change in the CPV variants has been observed around the world. Perez et al. (2012) showed that frequency of CPV-2a increased in a dog population from Uruguay, where CPV-2c was prevalent indicating change in variants. Similarly Xu et al. (2013) found that most of the isolates belonged to CPV-2a and found nucleotide identities of $98.8-100 \%$, whereas the amino acid similarities were $99.6-100 \%$. In similar studies conducted by Jing et al. (2011) in China and Yoon et al. (2009) in Korea, maximum number of isolates sequenced belonged to CPV-2a type. It has been observed that there is a dynamic change in $\mathrm{CPV}$ variants, stressing the need for more surveillance programs.

This study concludes that full length VP2 gene was successfully cloned (Acc. No. is KP406928.1 for P12, KP406927.1 for P15, KP406930.1 for P32, KP406926.1 for Megavac-6 and KP406929.1 for NobivacDHPPi) and sequence analysis revealed the samples belonged to CPV 2a. The samples were forming a separate clad among the Indian sequences indicating evolution in CPV. More surveillance studies are needed to further understand the evolution and regional variation among CPV types.

Acknowledgements. The authors are thankful to the University Grant Commission (UGC), New Delhi for the financial support (Grant No. 41-1170/2012(SR)) and Director of Research, GADVASU for providing the research facilities.

\section{References}

Biswas S, Das PJ, Ghosh SK, Pradhan NR (2006): Detection of canine parvovirus (CPV) DNA by polymerase chain reaction and its prevalence in dogs in and around Kolkata, West Bengal. Indian J. Anim. Sci. 76, 324-325.

Carmichael LE, Schlafler DH, Hashimoto A (1994): Minute virus of canines (MVC, canine parvovirus type 1 ): pathogenicity for pups and seroprevalence estimate. J. Vet. Diagn. Invest. 6, 165-174. http://dx.doi. org/10.1177/104063879400600206

Chinchkar SR, Mohan SB, Hanumantha RN, Rangarajan PN, Thiagarajan D, Srinivasan VA (2006): Analysis of VP2 gene sequences of canine parvovirus isolates in India. Arch. Virol. 151, 1881-1887. http://dx.doi.org/10.1007/ s00705-006-0753-8

Decaro N, Elia G, Desario C, Roperto S, Martella V, Campolo M, Lorusso A, Cavalli A, Buonavoglia C (2006): A minor groove binder probe real time PCR assay for discrimination between type- 2 based vaccines and field strains of canine parvovirus. J. Virol. Methods 136, 65-70. http:// dx.doi.org/10.1016/i.jviromet.2006.03.030

Hoelzer K, Shackelton LA, Holmes EC, Parrish CR (2008): Withinhost genetic diversity of endemic and emerging parvovi- 
ruses of dogs and cats. J. Virol. 82, 11096-11105. http:// dx.doi.org/10.1128/JVI.01003-08

Jing W, Li YingJun, Li Gang, Shi LiJun (2011): Cloning and analysis of VP2 gene of canine parvovirus isolated from Beijing. Chinese J. Vet. Sci. 31, 649-653.

Majer-Dziedzic B, Jakubczak A, Zietek J (2011): Phylogenetic analysis of canine parvovirus CPV-2 strains and its variants isolated in Poland. Polish J. Vet. Sci. 14, 379-384. http:// dx.doi.org/10.2478/v10181-011-0057-0

Mochizuki M, Ohshima T, Une Y, Yachi A (2008): Recombination between vaccine and field strains of Canine Parvovirus is revealed by isolation of virus in canine and feline cell cultures. J. Vet. Med. Sci. 70, 1305-1314. http://dx.doi. org/10.1292/jvms.70.1305

Mochizuki M, San Gabriel MC, Nakatani H, Yoshida M (1993): Comparison of polymerase chain reaction with virus isolation and haemagglutination assays for the detection of canine parvoviruses in faecal specimens. Res. Vet. Sci. 55, 60-63. http://dx.doi.org/10.1016/0034-5288(93)90035-E

MohanRaj J, Mukhopadhyay HK, Thanislass J, Antony PX, Pillai RM (2010): Isolation, molecular characterization and phylogenetic analysis of Canine Parvovirus. Infect. Genetics Evol. 10, 1237-1241. http://dx.doi.org/10.1016/j. meegid.2010.08.005

Nandi S, Anbazhagan R, Kumar M, Chauhan RS (2009b): Molecular characterization of canine parvovirus strains in vaccines by polymerase chain reaction and restriction endonuclease analysis. Indian J. Virol. 20, 12-15.

Nandi S, Chidri S, Kumar M (2009a): Molecular characterization and phylogenetic analysis of a canine parvovirus in India. Vet. Med. 54, 483-490.

Parthiban M, Saranya R, Divya KC, Kumanan K (2012): Detection of antigenic variation of canine parvovirus strains of Tamil Nadu using differential PCR. Indian J. Anim. Sci. 82, 237-239.

Pérez R, Bianchi P, Calleros L, Francia L, Hernández M, Maya L, Panzera Y, Sosa K, Zoller S (2012): Recent spreading of a divergent canine parvovirus type 2a (CPV2a) strain in a CPV-2c homogenous population. Vet.
Microbiology 155, 214-219. http://dx.doi.org/10.1016/j. vetmic.2011.09.017

Phromnoi S, Sinsiri R, Sirinarumitr T (2010): Expression of Recombinant VP2 Protein of Canine Parvovirus in Escherichia coli. Kasetsart J. 44, 870-878.

Ramadass P, Khader TGA (1982): Diagnosis of canine parvovirus infection by agar gel precipitation test and fluorescent antibody techniques. Cheiron 11, 323-325.

Rozen S, Skaletsky HJ (2007): Primer3 on the www for general users and for biologist programmers. In Krawetz S, Misener S (Eds): Bioinformatics Methods and Protocols: Methods in Molecular Biology. Humana Press, Totowa, NJ,pp. 365-386.

Sambrook J, Russell DW (2001): Molecular cloning: A laboratory Manual. 3rd ed. Cold Spring Harbor Laboratory Press, New York.

Shackelton LA, Parrish CR, Truyen U, Holmes EC (2005): High rate of viral evolution associated with the emergence of carnivore parvovirus. PNAS 102, 379-384. http://dx.doi. org/10.1073/pnas.0406765102

Singh D, Verma AK, Kumar A (2014): Phylogenetic analysis of Canine Parvovirus isolates from Mathura, India. Veterinaski Arhi 84, 505-512.

Tamura K, Stecher G, Peterson D, Filipski A, Kumar S (2013): Mega6: Molecular Evolutionary Genetics Analysis Version 6.0. Mol. Biol. Evol. 30, 2725-2729. http://dx.doi. org $/ 10.1093 / \mathrm{molbev} / \mathrm{mst} 197$

Xu J, Guo HC, Wei YQ, Shu L, Wang J, Li JS, Cao SZ, Sun SQ (2013): Phylogenetic analysis of Canine Parvovirus isolates from Sichuan and Gansu Provinces of China in 2011. Transbound. Emerging Dis. 10.1111/tbed.12078. http://dx.doi. org/10.1111/tbed. 12078

Ying H, Runxi X, Manfu Z (2009): Expression or subcellular targeting of virus capsid proteins with cloning genome of a Canine Parvovirus from China. Res. Vet. Sci. 87, 239-241. http://dx.doi.org/10.1016/j.rvsc.2009.03.001

Yoon SH, Jeong W, Kim HJ, An DJ (2009): Molecular insights into the phylogeny of canine parvovirus $2(\mathrm{CPV}-2)$ with emphasis on Korean isolates: a Bayesian approach. Arch. Virol. 154, 1353-1360. http://dx.doi.org/10.1007/ $\underline{\text { s00705-009-0444-3 }}$ 